\title{
Inorganic chemical analysis of plant tissue: possibilities and limitations
}

\author{
V. J. G. Houba, I. Novozamsky and J. J. van der Lee \\ Department of Soil Science and Plant Nutrition, Agricultural University, P.O. Box \\ 8005,6700 EC Wageningen, Netherlands
}

Received 14 May 1986; accepted 12 June 1986

Key words: plant tissue, chemical analysis, interlaboratorial variability, collaborative study

\begin{abstract}
The variability of analytical results for determination of 23 inorganic components in different plant materials was evaluated, using data over the last five years of an extensive (on the average 120 participants) bimonthly collaborative interlaboratory study. In particular, the relation between content level and coefficient of variation (c.v.) was examined. Usually, a constant c.v. value was found at high content levels, with a sharp increase in c.v. at low levels.

The precision found for $\mathrm{N}, \mathrm{P}, \mathrm{K}, \mathrm{Ca}, \mathrm{Cl}, \mathrm{Mg}, \mathrm{Zn}$ and nitrate was high enough (c.v. $<20 \%$ ) to yield reasonably comparable content values. Comparison of analytical results for $\mathrm{B}, \mathrm{Cu}, \mathrm{Fe}, \mathrm{Cd}, \mathrm{Mn}$ and $\mathrm{Na}$, may be difficult, since about $20 \% \mathrm{c} . \mathrm{v}$. was reached already at the levels usually present in plant material. The analytical results for $\mathrm{Al}, \mathrm{Co}, \mathrm{Cr}, \mathrm{Mo}, \mathrm{Ni}, \mathrm{Pb}, \mathrm{S}, \mathrm{Se}$ and sulphate varied considerably, irrespective of the content level, which means that comparable results are very hard to produce with these components.
\end{abstract}

\section{Introduction}

The chemical analysis of plant tissue has become important in the management of intensive crop production. The purpose of this kind of analysis is to measure the total content of elements or species in the plant tissue. The concentration values are then used to indicate nutrient sufficiency or deficiency or the toxicity situation of the crop.

Many laboratories are involved in plant tissue analysis. However, since no 'standard' method is used, the question of how well laboratories agree on the results of plant tissue analyses is often asked. In order to answer this question, a collaborative type study has to be conducted to evaluate interlaboratory variability associated with plant tissue analysis.

Such a collaborative study, intended as a means for comparison of chemical ana- 
lytical results, has been conducted by our university since 1956 , and at the time being about 190 laboratories from 54 countries all over the world are participating. In the following, the data from the period 1981-1985 are used to show the interlaboratory variability in the determination of various elements. All data were obtained by the particular methodology and instrumentation routinely used by each laboratory.

\section{Procedure}

For each parameter the average value and the standard deviation were calculated for all available data. Values differing by more than two times the standard deviation from this average were discarded. A second average and standard deviation were computed. This procedure was repeated and a third average and standard deviation were calculated. With this last set of data the coefficient of variation was calculated:

$$
\text { c.v. }=\frac{\text { standard deviation }}{\text { average }} \times 100 \%
$$

These coefficients of variation were then plotted as a function of corresponding average content of the parameters determined in the different plant tissues (Fig. 1). Because of the used calculation procedure and the fact that not all laboratories had determined all of the parameters, these average values and corresponding coefficients of variation are not always based upon equal numbers of analytical values. The number of values, however, was considered large enough to take the present parameters into consideration without introducing an additional variability.

\section{Results and discussion}

The general pattern in the results is, as expected, a constant coefficient of variation over a more or less broad range of concentrations, strongly increasing in the lower concentration range depending of the parameter under consideration (Fig. 1).

The 'constant' variability range can be considered as inherent to interlaboratory variation in cases where no analytical-technical difficulties are present. This 'constant' interlaboratory variability amounts to about $10 \%$ for the following parameters:

$$
\begin{aligned}
& \mathrm{CV}=5-10 \% \text { for } \mathrm{Cl}, \mathrm{K}, \mathrm{Mg}, \mathrm{N}_{\text {total }}, \mathrm{P} \\
& \mathrm{CV}=10 \% \text { for } \mathrm{Ca}, \mathrm{Cu}, \mathrm{Mn}, \text { nitrates, } \mathrm{Zn} \\
& \mathrm{CV}=10-15 \% \text { for } \mathrm{B}, \mathrm{Fe}, \mathrm{Na}
\end{aligned}
$$

For the other parameters studied no such clear-cut trend was observed, which indicates that the analytical difficulties are such that interlaboratory comparison is not feasible. This is the case for $\mathrm{Al}, \mathrm{Co}, \mathrm{Cr}, \mathrm{Mo}, \mathrm{Ni}, \mathrm{Pb}, \mathrm{Se}$ and sulphate. For all these parameters, with the exception of $\mathrm{Al}$ and sulphate, holds that the content in plant material is very low. This necessarily means that chemical analyses are not easy to perform.

In the case of $\mathrm{Al}$ and sulphate, the concentrations are reasonably high. The high 

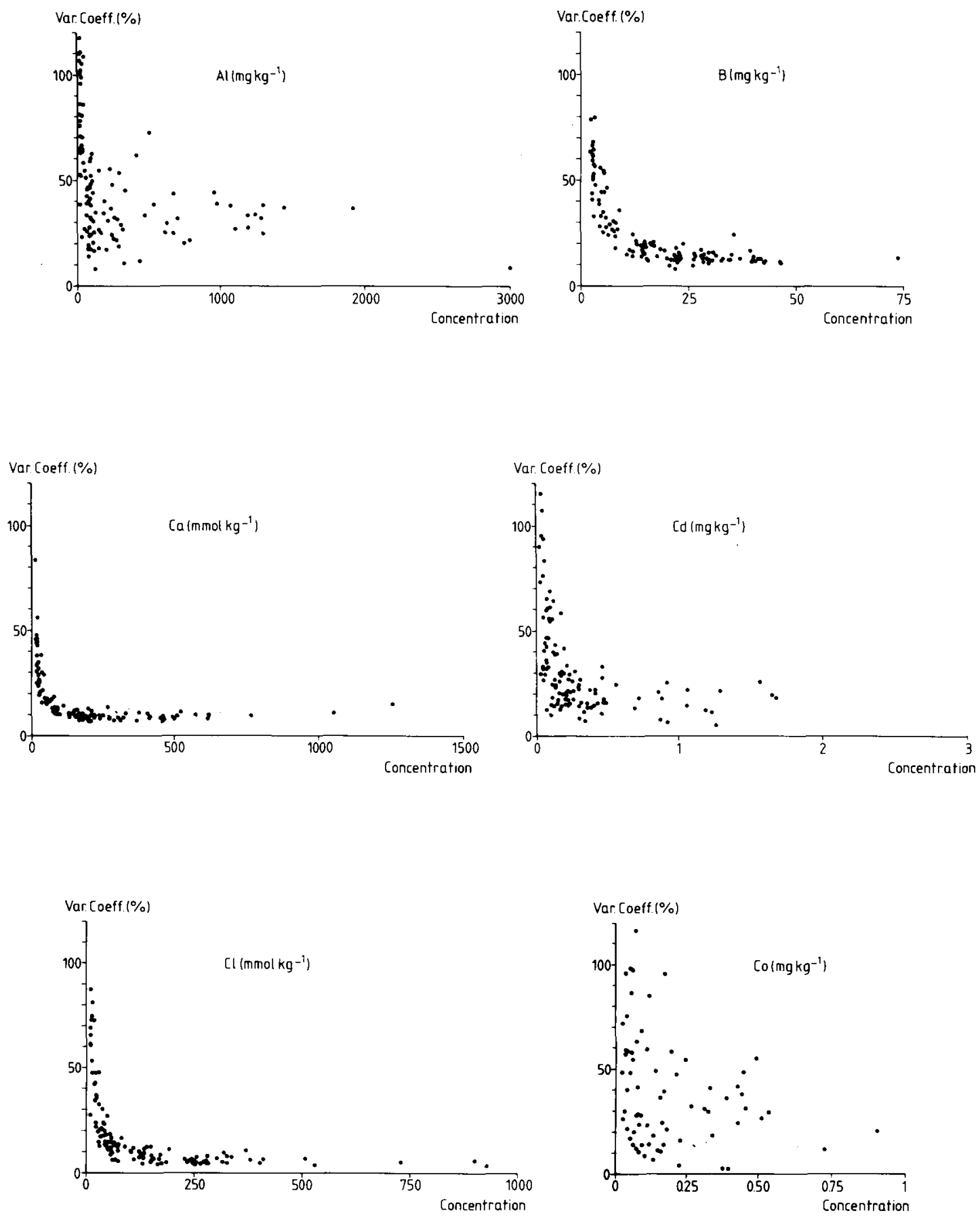

Fig. 1. Interlaboratory variability of chemical analysis of plant tissue in relation to concentration. 


\section{J. G. HOUBA, I. NOVOZAMSKY AND J. J. VAN DER LEE}
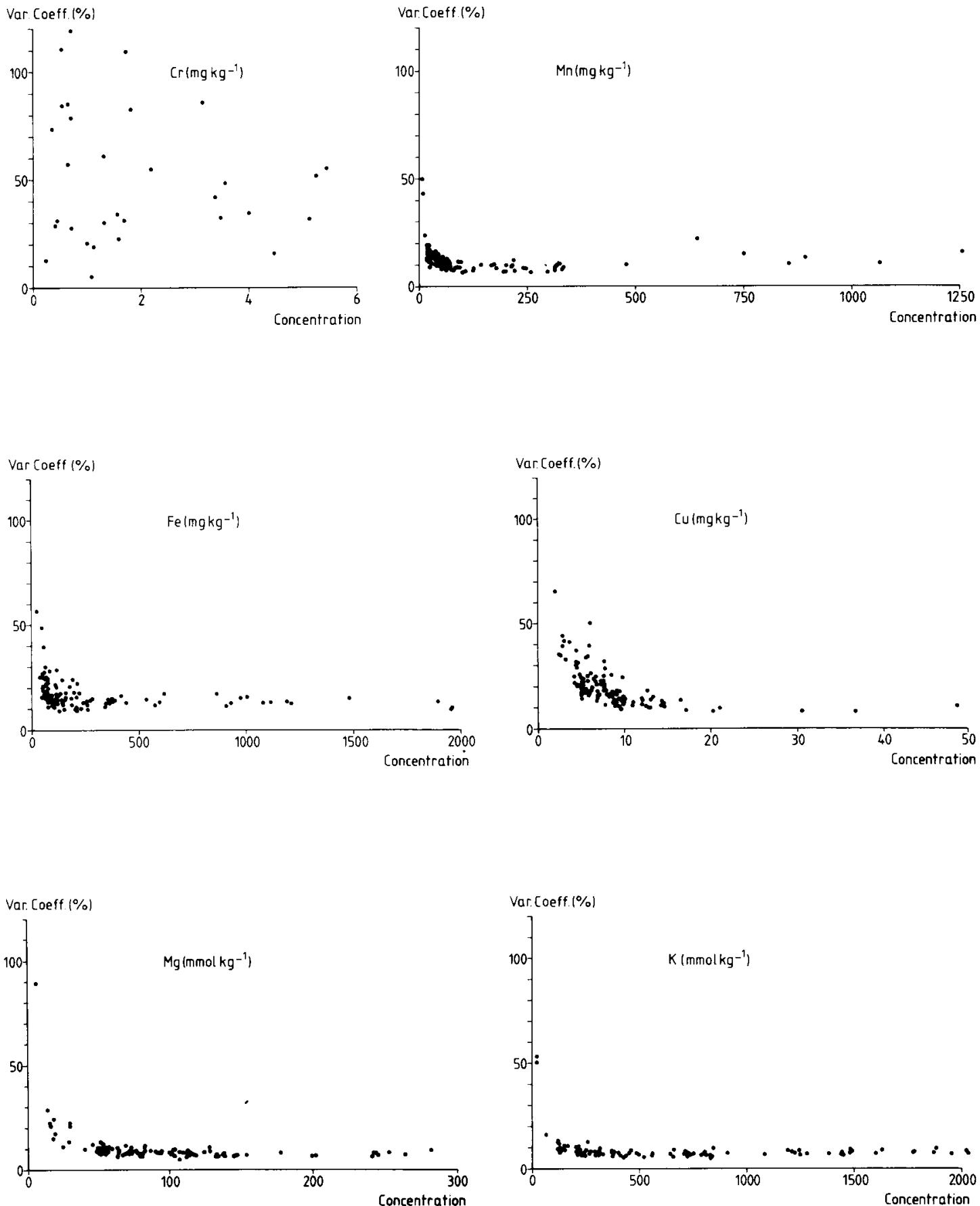

Fig. 1 (continued). 
INORGANIC CHEMICAL ANALYSIS OF PLANT TISSUE
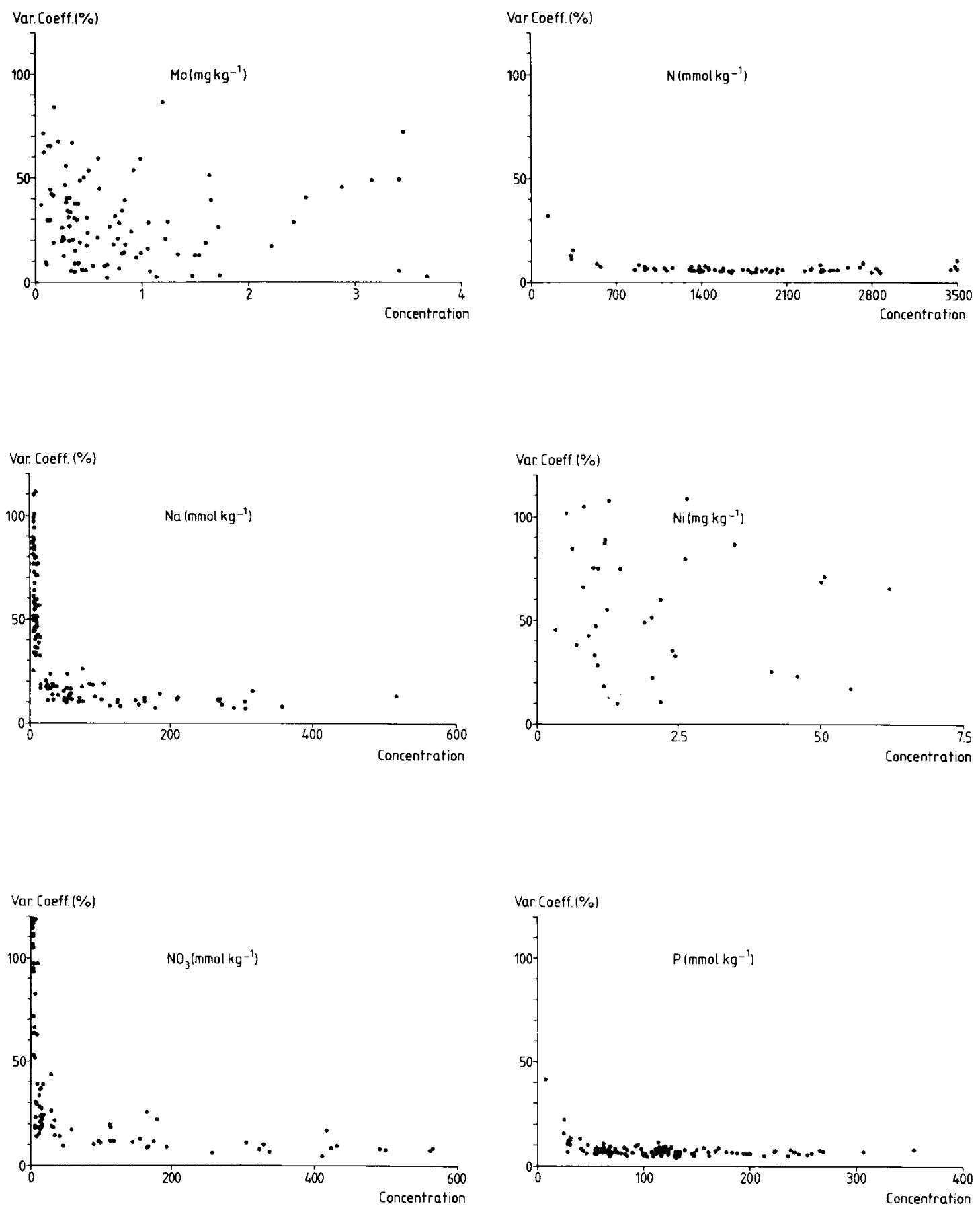

Fig. 1 (continued).

Netherlands Journal of Agricultural Science 34 (1986) 


\section{J. G. HOUBA, I. NOVOZAMSKY AND J. J. VAN DER LEE}
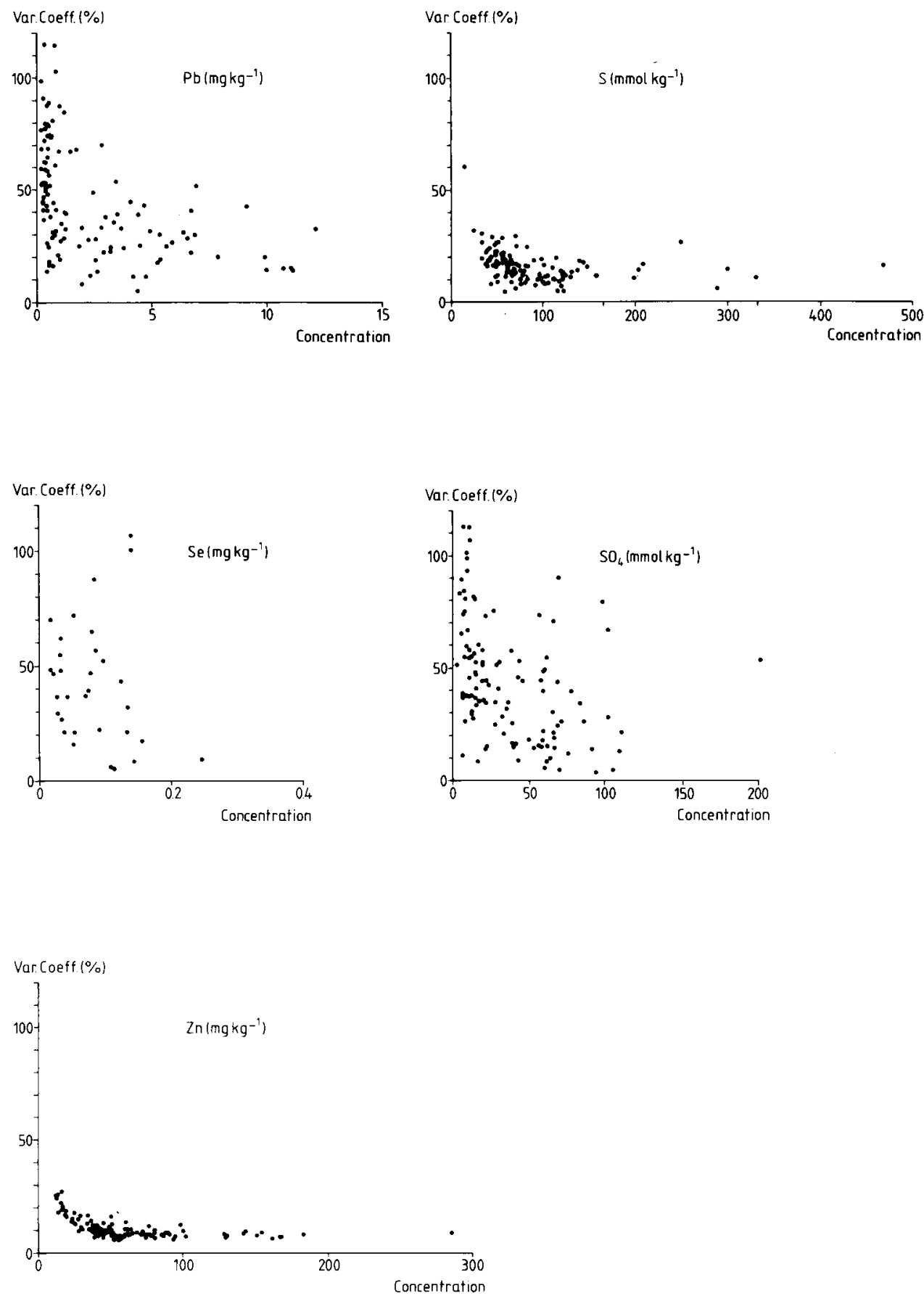

Fig. 1 (continued). 
variation encountered may therefore be ascribed to less adequate analytical procedures. For example, it is known (Daniel et al., 1984; Ledent et al., 1984) that in case dry ashing is used without subsequent expulsion of silica, often too low Al values are found. This may be one of the causes of the high variability with this element.

The situation for total S and Cd is not a clear-cut one either. In the case of sulphur, losses during the digestion or incomplete digestion (compounds such as methionine are very difficult to digest; Novozamsky \& van Eck, 1977) may be one reason for the somewhat higher interlaboratory variability.

Although $\mathrm{Cd}$ shows a more or less constant pattern at higher content levels, in the plant tissue analysed the concentrations were apparently at the lower level.

\section{Conclusions}

The data presented here can be used for the assessment of the possibilities and limitations of plant analysis data for the evaluation of the nutrient status of plants. For that purpose, a maximum acceptable c.v. value must be chosen. Then, the lowest content value can be estimated from the graphs for the different parameters. Table 1 gives these values for a chosen c.v. level of $20 \%$, together with values for 'normal' content ranges as reported by different authors. No analytical problems are to be expected with the determination of $\mathrm{K}, \mathrm{N}$ and $\mathrm{P}$, since the normal levels are much higher than the values that correspond with $20 \%$ c.v. (Fig. 1). From Table 1 it is apparent that the situation for $\mathrm{Ca}, \mathrm{Cl}, \mathrm{Mg}$ and $\mathrm{Zn}$ is also favourable. Comparison of results is difficult for $\mathrm{B}, \mathrm{Cu}, \mathrm{Fe}$ and $\mathrm{Mn}$, since values that correspond with $20 \%$ c.v. fall in the range of normal values. The remaining parameters, i.e. $\mathrm{Al}, \mathrm{Co}, \mathrm{Cr}, \mathrm{Mo}$, $\mathrm{Ni}, \mathrm{Pb}, \mathrm{S}, \mathrm{Se}$ and sulphate, pose severe problems with respect to the comparability of analytical results from different laboratories.

Generally speaking, the present results reveal that for a great number of parameters further analytical chemical investigations and optimisation of the methods used are urgently needed.

Table 1. Lowest measurable level of some nutrient elements for a chosen interlaboratory variability level of $20 \%$ c.v., compared to literature values for 'normal' nutrient contents.

\begin{tabular}{|c|c|c|c|c|c|}
\hline & & Lowest & 'Normal contel & ange' & \\
\hline & & $\begin{array}{l}\text { measurable } \\
\text { content }\end{array}$ & $\begin{array}{l}\text { Benton Jones } \\
\text { (1972) }\end{array}$ & $\begin{array}{l}\text { Finck } \\
(1968)\end{array}$ & $\begin{array}{l}\text { Mengel \& Kirkby } \\
(1982)\end{array}$ \\
\hline $\mathrm{Ca}$ & $\left(\mathrm{mmol} \mathrm{kg}^{-1}\right)$ & 30 & & $250-500$ & $125-175$ \\
\hline $\mathrm{Cl}$ & $\left(\mathrm{mmol} \mathrm{kg}^{-1}\right)$ & 40 & & & $60-600$ \\
\hline $\mathrm{Mg}$ & $\left(\mathrm{mmol} \mathrm{kg}^{-1}\right)$ & 15 & & $80-160$ & \pm 200 \\
\hline $\mathrm{Na}$ & $\left(\mathrm{mmol} \mathrm{kg}{ }^{-1}\right)$ & 30 & & & \\
\hline $\mathrm{NO}_{3}$ & $\left(\mathrm{mmol} \mathrm{kg}{ }^{-1}\right)$ & 15 & & & \\
\hline B & $\left(\mathrm{mg} \mathrm{kg}^{-1}\right)$ & 10 & $20-100$ & $5-30$ & $3-100$ \\
\hline $\mathrm{Cu}$ & $\left(\mathrm{mg} \mathrm{kg}^{-1}\right)$ & 7.5 & $5-20$ & $5-10$ & $2-20$ \\
\hline $\mathrm{Fe}$ & $\left(\mathrm{mg} \mathrm{kg}^{-1}\right)$ & 200 & $50-200$ & & \pm 100 \\
\hline Mn & $\left(\mathrm{mg} \mathrm{kg}^{-1}\right)$ & 25 & $20-500$ & $40-80$ & 20 \\
\hline $\mathrm{Zn}$ & $\left(\mathrm{mg} \mathrm{kg}^{-1}\right)$ & 15 & $25-150$ & $20-30$ & $20-120$ \\
\hline
\end{tabular}




\section{Acknowledgement}

The data acquisition was greatly simplified by computer programmes developed by Mr I. Made Suwetja. Furthermore we want to thank Mr Ch. Koot for his help offered in the organization of the sample exchange programme.

\section{References}

Benton Jones, Jr., J., 1972. Plant tissue analysis for micronutrients. In: J. J. Mortvedt et al. (Eds.), Micronutrients in agriculture, p. 319-347. American Soil Science Society, Madison, Wisconsin, USA.

Daniel, R. Ch. et les Membres du C.I.I. 1984. Les étalons végétaux du C.I.I. Résultats complémentaires. Comm. VIe Colloque International pour l'Optimisation de la Nutrition des Plantes (Montpellier, France): 837-846.

Finck, A., 1968. Grenzwerte der Nährelementgehalte in Pflanzen und ihre Auswertung zur Ermittlung des Düngerbedarfs. Zeitschrift für Pflanzenernährung, Düngung und Bodenkunde 119: 197-208.

Ledent, G., R. de Borger \& S. van Hentenrijk, 1984. Etude de deux minéralisations appliquées aux dosage des éléments minéraux dans les végétaux. Analusis 12: 393-395.

Mengel, K. \& E. A. Kirkby, 1982. Principles of plant nutrition, 3rd ed. International Potash Institute, Bern, Switzerland, $655 \mathrm{pp}$.

Novozamsky, I. \& R. van Eck, 1977. Total sulphur determination in plant material. Zeitschrift für Analytische Chemie 286: 367-368. 